\title{
The Impact of Financial Technology Peer-to-Peer Lending (P2P Lending) on Growth Credit Rural Bank
}

\author{
$1^{\text {st }}$ Agustina Eka Harjanti \\ Department of Accounting \\ Universitas Muhammadiyah Kudus \\ Kudus, Indonesia \\ agustinaeka@umkudus.ac.id
}

\author{
$2^{\text {nd }}$ Hasna Mudiarti \\ Department of Accounting \\ Universitas Muhammadiyah Kudus \\ Kudus, Indonesia
}

\author{
$3^{\text {rd }}$ Bonnix Hedy \\ Department of Accounting \\ Universitas Muhammadiyah Kudus \\ Kudus, Indonesia
}

\begin{abstract}
The competition faced by the Rural Bank (BPR) industry is getting more intensed. A few years ago, the Commercial Bank through the Micro Credit Program (Kredit Usaha Rakyat/KUR) became main competitor in distributing working capital loans or tconsumptive loans. However, new competitor is currently emerging in the financial sector, that is institution based on financial technology (fintech). Fintech can provide financial products and services that are easy, effective, efficient, and fast. The focus of this research is on fintech peerto-peer lending (p2p lending). The purpose of this study is to describe the impact of financial technology peer-to-peer lending on BPR credit growth. This study used qualitative descriptive approach with literature review method. Data analyzed used reducing data, presenting data, and making conclusions. The result showed that peer-to-peer lending impacting BPR credit growth due to regulations and relevant institutions that supporting fintech's development. BPRs must be able to develop or innovate the products and services provided to the public or customers. BPRs can also collaborate with Fintech p2p lending to advance improvement and efficiency in term of services provided by the BPRs.
\end{abstract}

Keywords-Financial, Technology, peer-to-peer Lending, P2P Lending, Bank

\section{INTRODUCTION}

The development of the financial industry in the era of industrial revolution 4.0 is getting tougher. Many banking industries develop their business by releasing various types of products which facilitate customers in the use of their services. In Indonesia, many banks have innovated in providing services to customers. The innovations consist of developing digital banking and branchless banking. Banking industry in Indonesia is divided into two types; commercial or full-service bank and rural bank. The commercial or fullservice banks carry out their activities conventionally or based on sharia principles by providing services in payment traffic, while rural banks carry out their activities conventionally or based on sharia principles by not providing services in payment traffic[1]. Both types of banks each have intense competition because of the new competitors that emerge in the financial sector, such as technology-based financial company or commonly called Fintech (financial technology). Fintech can provide products and financial services easily, effectively, efficiently, and quickly. Especially in the type of peer to peer lending (P2P lending) business which the activities are almost similar to what the industrial banking carried out. The activities of the fintech business type are to connect the lenders and the borrowers into an agreement via smartphones and internet networks.

A few years ago, the Commercial Bank through the Kredit Usaha Rakyat (KUR) or People's Business Loans program became the main competitor of Rural Bank in attracting public interest to conduct the working capital loans or consumer loans. But recently, fintech ( $\mathrm{P} 2 \mathrm{P}$ lending) is becoming an additional competitor in providing credit to the public. The growth of Rural Bank loans for the first quarter of 2019 [2] as follows. 


\begin{tabular}{|c|c|c|c|c|c|c|c|}
\hline \multirow{2}{*}{ Indikator } & \multicolumn{2}{|c|}{ Nominal } & \multirow[b]{2}{*}{ Mar '19 } & \multicolumn{2}{|c|}{ qtq } & \multicolumn{2}{|l|}{ yoy } \\
\hline & Mar '18 & Des '18 & & Des '18 & Mar '19 & Mar '18 & Mar '19 \\
\hline Total Aset (Rp milyar) & 127.528 & 135.693 & 137.440 & $3,18 \%$ 亿 & $1,29 \%$ 亿 & $11,02 \% \hat{\imath}$ & $7,77 \%$ \\
\hline Kredit (Rp milyar) & 91.655 & 98.220 & 101.465 & $2,53 \% \hat{\imath}$ & $3,30 \%$ 亿 & $8,67 \%$ 亿 & $10,70 \%$ \\
\hline Dana Pihak Ketiga (Rp milyar) & 86.361 & 91.956 & 93.782 & $3,62 \%$ 亿 & $1,99 \%$ 亿 & $11,85 \%$ 亿 & $8,59 \%$ \\
\hline - Tabungan (Rp milyar) & 26.999 & 29.491 & 29.609 & $5,57 \%$ 亿 & $0,40 \%$ 亿 & $14,40 \%$ 亿 & $9,66 \%$ \\
\hline - Deposito (Rp milyar) & 59.362 & 62.465 & 64.173 & $2,72 \% \hat{\imath}$ & $2,73 \%$ 亿 & $10,73 \%$ 个 & $8,11 \%$ \\
\hline CAR (\%) & 24,10 & 23,35 & 24,19 & 60 & 84 & 38 & 9 \\
\hline ROA (\%) & 2,68 & 2,48 & 2,42 & (1) & (6) & (8) & (26) \\
\hline ВОРО (\%) & 80,59 & 80,74 & 81,92 & (50) & 118 & (22) & 133 \\
\hline NPL Gross (\%) & 6,81 & 6,37 & 6,94 & (79) & 57 & 13 & 13 \\
\hline NPL Net (\%) & 5,10 & 4,74 & 5,28 & (63) & 54 & 21 & 18 \\
\hline LDR (\%) & 75,43 & 76,54 & 77,36 & (40) & 82 & (157) & 193 \\
\hline CR (\%) & 16,93 & 18,84 & 15,01 & 266 & (383) & 167 & (192) \\
\hline
\end{tabular}

Source: [2]

Fig. 1. Rural Banks (BPR) Growth Indicator in March 2019

Based on the data, the Rural Banks (BPR) intermediary function is running quite well, it can be seen from the increase in credit growth. The Capital Adequacy Ratio (CAR) obtained by the Rural Banks also quite high although still take notice of the increase of Non-Performing Loan (NPL). The assets growth slowed by $7.77 \%$ (yoy) compared to the previous year that grew by $11.02 \%$ (yoy). The growth of Rural Banks is significant to the growth of Third-Party Funds (DPK; Dana Pihak Ketiga). This can be seen from the deceleration assets caused by Third-Party Funds that getting weaker. The Third-Party Funds of Rural Banks 8.59\% (yoy), slowing compared to $11.85 \%$ (yoy) in the previous year. The deceleration occurred due to two components, i.e. on the savings and deposits which recorded $9.66 \%$ (yoy) and $8.11 \%$ (yoy). The growth of Rural Banks credits appear to be stagnant in the last year, increasing by $2.03 \%$. The slowing growth of BPRs' (Rural Banks) Third-Party Funds and the growth of Rural Banks that was stagnant caused by the tight competition with the technology-based financial company. The number of registered and licensed Fintech companies is 144 companies. These companies that spread out in Indonesia with the following data [3]:

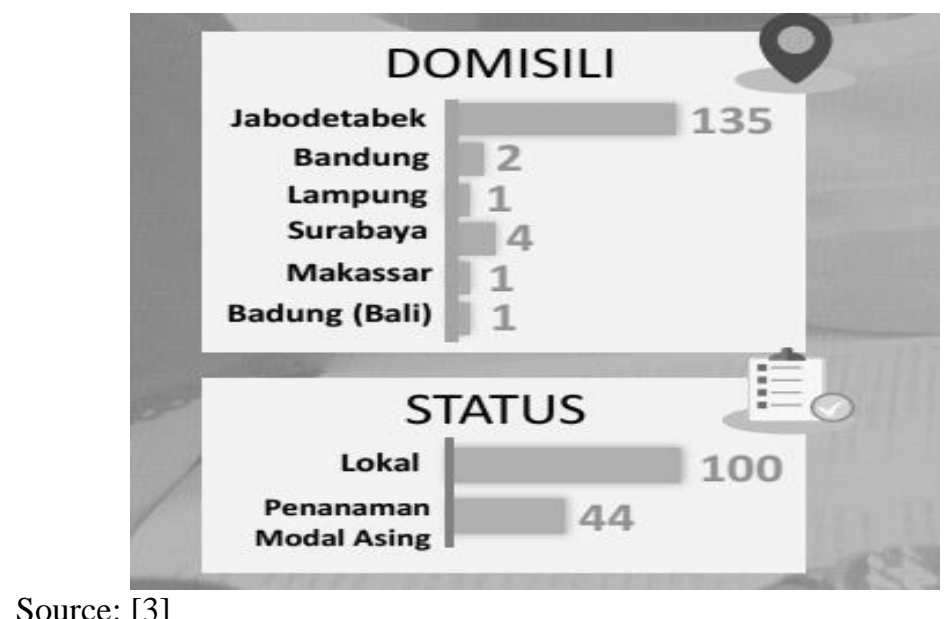

Source: [3]

Fig. 2. Fintech Companies Data in November 2019

While the distribution of funds lending in the last three years showed a very significant increase in Fintech companies. In December 2017 to December 2018, the distribution of funds lending in Java increased by $797.56 \%$ while in December 2018 to October 2019, the loans increased to $197.18 \%$. The increase in loans outside Java in
2017 increased by $705.82 \%$ while in 2018 to October 2019 increased by $218.20 \%$. Based on the data in Image 3, can be concluded that the accumulation of loans distribution up to October 2019 was IDR 68 trillion with a percentage increase by $200.01 \%$ (ytd). 


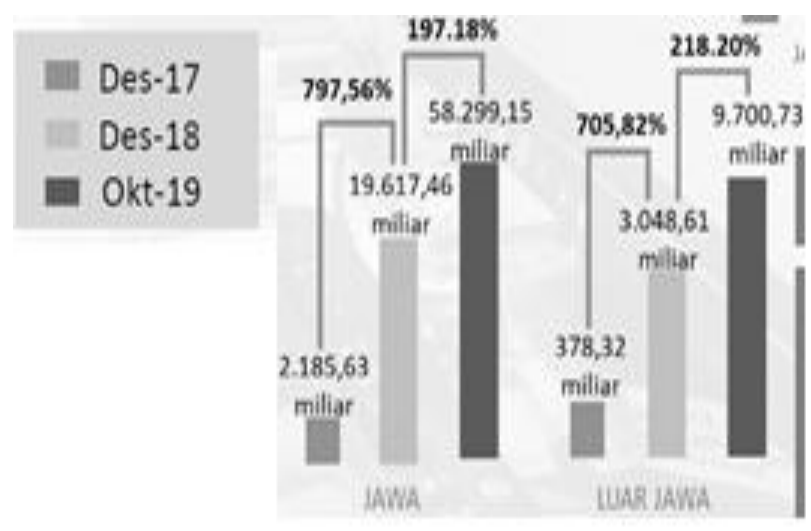

Source: [3]

Fig. 3. Fintech Company's Loan Distribution

Based on the data above, the development of Fintech companies in Indonesia is rapid, and the interest of lending activities is very large. This resulted in the competition between BPRs (Rural Banks) and Commercial or FullService Bank with Fintech that is getting tougher. Furthermore, the simplicity between lender and borrower to do a lending activities in fintech is another advantage that support fintech massive growth .

\section{LITERATURE REVIEW}

\section{A. Rural Bank (BPR)}

Rural Bank (Bank Perkreditan Rakyat, or BPR) is a business entity that the activity is to collect funds from the public in the form of deposits and distribute them to the public in the form of credit and/or other forms in term of enhancing the people's standard of living by carrying out business activities conventionally or based on sharia principles [1]. The Rural Bank activities use basic and certain principles as a reference in making necessary decisions. The basic principle used is the prudential banking principle. This principle states that banks in carrying out their business functions and activities must be prudent in protecting the public funds entrusted to them.

The permitted activities of Rural Bank are collecting funds in the form of deposits; such time deposits, savings, and other equivalent forms, lending, providing financing and placing funds based on sharia principles based on the conditions set by Bank Indonesia, and placing funds in the form of Bank Indonesia Certificates (Sertifikat Bank Indonesia, SBI) [1]. The limitation of Rural Bank activities is that Rural Banks are prohibited accepting demand deposits and participating in payment traffic, conducting in foreign currency activities, equity participation, insurance, and other business besides of the business activities as regulated in Article 13.

\section{B. Financial Technology}

Fintech is a business topic which is widely discussed. The development of Fintech is closely related to technological development. Fintech is a digital technology application that is useful in providing solutions to financial problems that occur in the society [4]. Several sources define Financial Technology as follows: Fintech is a business line based on the software used to provide financial services. Generally, Fintech is a start-up company that was established to provide financial services by utilizing modern software and technology [5]. Meanwhile, [6] describe that Fintech is a cross-disciplinary subject that combines finance, technology management, and innovation management. Furthermore, it explained that each innovative idea can improve the financial services process by using technologyadjusted to each business situation, while the idea can also bring a new business model or even become a new type of business.

The types of Fintech services are divided into three types, i.e. (a) Payment systems through third parties, (b) Peer to Peer Lending, and (c) Crowdfunding. Examples of payment systems through third parties namely; crossborderEC, online to offline $(\mathrm{O} 2 \mathrm{O})$, mobile payment, and payment platforms that provide transfer services [7]. Crowdfunding is a type of Fintech that has concepts/products such as designs, programs, content, and creative works that are published to the public and if people are interested in the concept or product, then they can provide economic support (financial). Meanwhile, peer to peer lending will be discussed in the following discussion.

Fintech has benefits in facilitating services to the public that have not been served by the traditional financial industry due to the strict of banking regulations and limitations of the traditional banking industry in serving people in certain regions, also become the alternative choice in conducting funding activities other than traditional financial industry services [8].

\section{Peer-to-peer Lending (P2P Lending)}

Peer to Peer Lending (P2P Lending) is the management of financial services in bringing together the lenders with the borrower. The difference with banking (Commercial and Rural Banks) is the mechanism. In the implementation of loan transactions, P2P Lending works through an electronic system using the internet network, so that it can be accessed more widely and quickly [9]. In Indonesia, Peer to Peer Lending activities are regulated in Article 5 of the second part concerning to the business activities of the Financial Services Authority Regulation No. 77 / POJK.01/2016 about Information Technology-based Lending and Borrowing Services from the Lender to the Loan recipient, that source of funds comes from the Loan Recipient. 
Peer to peer lending ( $\mathrm{P} 2 \mathrm{P}$ Lending) is a method of allocating money to individuals or businesses and vice versa, applying for a loan from a lender, which connects lenders with borrowers or investors online [10]. Peer to peer lending allows anyone to lend or apply for one loan to another for various purposes without using the services of a legitimate financial institution as an intermediary. P2P Lending is a marketplace that is used for lending and borrowing money without having to apply for loans through official institutions (banks, cooperatives, governments, and other credit services) as another solution that people can apply for loans without a complex process.

$\mathrm{P} 2 \mathrm{P}$ Lending is beneficial for borrowers and lenders. The benefit gotten by the borrower in carrying out this activity is obtaining a loan at a lower grade without collateral. While the lenders get high investment returns [11].

\section{RESEARCH METHODOLOGY}

This research uses a descriptive qualitative approach. The qualitative approach is explained descriptively by describing an event, phenomenon, and events that occur, then explained and described as they should [12]. According to [13], qualitative research is defined as an approach used to explore deeply and understand the meaning of several individuals or groups as a source of social problems.

The method used in this research is the study of literature. The reason for researchers uses this method since Fintech is considered a new topic. A literature study is a method used to collect data and library resources related to Fintech peer to peer lending. The data and sources of literature that have been obtained are analyzed by describing the facts and provide sufficient understanding and explanation [14].

\section{RESULT AND DISCUSSION}

The various advantage that Fintech peer to peer lending offered will influence Indonesians in using technologybased financial services (Fintech). It can replace the banking functions of both Commercial Banks or Rural Banks as fintech are much easier, faster, and efficient.

The reason for Fintech growing is the change in consumers' mindset, as the millennial now wish for accessibility and easiness to fulfil their financial needs. The advancement of the digital world and smartphones usage also induce the development of Fintech, which fintech now enable their customer to do their own financial transactions from their gadget rather than from the bank office. The type of Fintech that is most sought after by Indonesians is peer to peer lending (P2P Lending). Peer to Peer Lending users, both lenders and borrowers, amounted to 578,158 for lenders and 15,986,723 for borrowers. This data makes it clear that P2P Lending enthusiasts are very numerous since the customers can easily borrow money for business or consumption needs without having to go to a bank office. The conditions for making loans in P2P Lending are relatively easier than the conditions that must be put forward when the customers want to borrow funds from the banks.

The developing of Fintech Peer to Peer Lending makes the Financial-Services-Authority (Otoritas Jasa Keuangan/OJK) issued various regulations related to the implementation of Fintech. OJK issued the Financial Services Authority Regulation No. 77/POJK.01/2016 towards information-technology based lending and borrowing services. Aside from those regulations, OJK also issued Financial Authority Regulation No. 13/POJK.02/2018 regarding digital financial innovations, which contains that fintech companies produce digital financial innovations that are responsible, secure, prioritize consumer-protection, and have well-managed risks. With this regulation from OJK, users will trust Fintech's services more, without having to worry about deception.

For this reason, Rural Banks with a relatively small business scale and core capital must be able to keep up with fast and sophisticated service developments. Rural Bank (Bank Perkreditan Rakyat, or BPR) must be able to develop creativity in term of service that more innovative and suitable to people's needs. For example, by innovating products with technology systems to keep up with the times and be able to work with Fintech lending. Thus, the rural banks' credit growth will have a positive impact since they are able to provide services which appropriate with public expectations, viz fast, efficient, and easy, so they are able to compete.

\section{CONCLUSION}

Based on the discussion above, it can be concluded that Fintech peer to peer lending has an impact on rural banks' credit growth due to the existence of regulations that support the development of fintech and other relevant institutions. Rural banks must be able to develop or innovate the products and services provided to the public or customers. Other than innovation enhancement, BPRs can also collaborate with Fintech p2p lending to advance improvement and efficiency in term of services provided by the BPRs. Collaboration with Fintech can be in the form of connecting between the lenders and the borrower in order to fullfill the value chain of financing. With these alternatives, BPR will continue to be able to develop technological innovations with more efficient cost allocation, considering that BPR has small business scale and not too large core capital.

\section{ACKNOWLEDGMENT}

I would like to special thanks for my Rector of Muhammadiyah University of Kudus, chairperson of LPPM Muhammadiyah University of Kudus, and all lecturers who helped me a lot in finalizing this project. Secondly, I would like to very special thanks to my sister, which helped me as always. Thanks a lot.

\section{REFERENCES}

[1] Bank Indonesia, "Undang-Undang Nomor 10 Tahun 1998 Tentang Perbankan," Undang. NOMOR 10 TAHUN 1998 tentang Perbank., 1998.

[2] Otoritas Jasa Keuangan, "Laporan Profil Industri Perbankan Triwulan I 2019," 2019.

[3] Otoritas Jasa Keuangan, "Perusahaan Fintech Terdaftar/Berizin (Peraturan OJK No . 77 Tahun 2016)," pp. 1-11, 2019.

[4] M. Aaron, F. Rivadeneyra, and S. Sohal, "Fintech: Is this time different? A framework for assessing risks and opportunities for central banks," Bank Canada Staff Discuss. Pap., vol. 10, pp. 132, 2017.

[5] fintechweekly, "Fintech Definition," 2019. [Online]. Available: https://www.fintechweekly.com/fintech-definition. 
[6] K. Leong, "FinTech (Financial Technology): What is It and How to Use Technologies to Create Business Value in Fintech Way?," Int. J. Innov. Manag. Technol., vol. 9, no. 2, pp. 74-78, 2018.

[7] S. C. Hsueh and C. H. Kuo, "Effective matching for P2P lending by mining strong association rules," ACM Int. Conf. Proceeding Ser., vol. Part F130952, pp. 30-33, 2017.

[8] M. Ansori, "PERKEMBANGAN DAN DAMPAK FINANCIAL TECHNOLOGY (FINTECH) TERHADAP INDUSTRI KEUANGAN SYARIAH DI JAWA TENGAH," Wahana Islam. J. Stud. Keislam. Vol . 5 No. 1 Apr i l 201 9, vol. 53, no. 9, pp. 1689-1699, 2018.

[9] C. Stern, M. Makinen, and Z. Qian, "FinTechs in China - with a special focus on peer to peer lending," J. Chinese Econ. Foreign Trade Stud., vol. 10, no. 3, pp. 215-228, 2017.
[10] B. Murifal, "Peran Teknologi Finansial Sistem P21 Sebagai Alternatif Sumber Pendanaan UMKM," vol. XVI, no. 2, 2018.

[11] J. R. Magee, "Peer-to-Peer Lending in the United States: Surviving after Dodd-Frank," North Carolina Bank. Inst., vol. 15, no. 1, 2011.

[12] B. M. Miles and A. M. Huberman, Analisis Data Kualitatif: Buku Sumber Tentang Metode-Metode Baru, 1st ed. Jakarta: UI-Press, 2014.

[13] J. W. Creswell, Research Design: Pendekatan Metode Kualitatif, Kuantitatif, dan Campuran, 4th ed. Yogyakarta: Pustaka Pelajar, 2017.

[14] B. A. Habsy, "Seni Memehami Penelitian Kuliatatif Dalam Bimbingan Dan Konseling: Studi Literatur," JURKAM J. Konseling Andi Matappa, vol. 1, no. 2, p. 90, 2017. 